\title{
Mushrooms as a Source of Polyprenols
}

\section{Tatyana P. Kukina, ${ }^{1}$ Irina A. Gorbunova, ${ }^{2}$ and $\mathcal{E}^{2}$ I. Bayandina ${ }^{2}$}

${ }^{1}$ Novosibirsk Institute of Organic Chemistry, Siberian Branch of the Russian Academy of Sciences, 9 Prosp. Acad. Lavrent'ev, 630090 Novosibirsk, Russia, email: kukina@nioch.nsc.ru; ${ }^{2}$ Central Siberian Botanical Garden, Siberian Branch of the Russian Academy of Sciences, 101 Zolotodolinskaya St., 630090 Novosibirsk, Russia, emails: gorbunova@nsk.csbg.ru, bayandina@ngs.ru

Accumulation of long chain polyprenols in leaves of plants was first described 50 years ago. Polyprenols were found in a number of angiosperm plants and conifer trees (Chojnacki and Vogtman, 1984). These compounds have a broad spectrum of physiological activity. Dolichols are partially hydrogenated polyprenols. The physiological activity of dolichols is several times higher than polyprenol activity (Grigor'eva and Moiseenkov, 1989). Dolichols occur in mammalian tissues and yeast, and they are also found in some plants (Mankowski et al., 1976; Kukina et al., 1991). Bactoprenols were found in bacteria, but the data about "fungoprenols" are absent in scientific literature.

Polyprenols were isolated from the following mushrooms: Armillaria mellea (Vahl:Fr.) P. Kumm., Fomes fomentarius (L.:Fr.) J.J. Kickx, Tricholoma populinum J. Lge, Lycoperdon perlatum Pers.:Pers., and Suillus luteus (L.:Fr.) S.F. Gray. The samples of fresh mushrooms were extracted by a mixture of hexane and isopropanole in a ratio of 1:1. Adding water to the extract formed two layers of liquid. The hexane included the nonpolar substances and alcohol included a number of polar components. These fractions may be investigated separately. Samples of extracts were investigated by high-performance liquid chromatography with the ester of tocopherol as an internal standard. HPLC was performed as described previously (Mankowski et al., 1976) for plantaprenols from sea buckthorn leaves. The yields of extractive substances from these samples and content of polyprenols in extracts are presented in Table 1.

The distribution of polyprenols in free and esterified forms is summarized in Table 2. The accurate analysis of chromatographic data led to conclusions about the differences of polyprenols. Armillaria mellea, Lycoperdon perlatum, and Tricholoma populinum contain predominantly acetylated polyprenols. Polyprenols from Suillus luteus were investigated after saponification because the polyprenols were esterified with fatty acids. S. luteus probably contain small amounts of dolichols. The polyprenols in Fomes fomentarius and S. luteus are present in minute amounts.

According to this research, mushrooms are being considered as new sources of polyprenols. 
TABLE 1. Polyprenols Accumulation in Different Species of Mushrooms

\begin{tabular}{|l|c|c|c|c|}
\hline \multicolumn{1}{|c|}{ Species } & $\begin{array}{c}\text { Yield of hexane } \\
\text { extract } \% \text { from } \\
\text { dry weight) }\end{array}$ & $\begin{array}{c}\text { Content of } \\
\text { polyprenols in } \\
\text { hexane extract }\end{array}$ & $\begin{array}{c}\text { Yield of alcohol } \\
\text { extract (\% from } \\
\text { dry weight) }\end{array}$ & $\begin{array}{c}\text { Content of } \\
\text { polyprenols in } \\
\text { alcohol extract }\end{array}$ \\
\hline Armillaria mellea & 3.0 & 3.2 & 10.2 & Traces \\
\hline Fomes fomentarius & 0.7 & 0.2 & 12.0 & Traces \\
\hline Tricholoma populinum & 2.5 & 2.0 & 8.2 & Traces \\
\hline Lycoperdon perlatum & 0.7 & 1.1 & 4.0 & Traces \\
\hline Suillus luteus & 2.5 & 0.5 & 30.0 & Traces \\
\hline
\end{tabular}

TABLE 2. Distribution of Polyprenols

\begin{tabular}{|c|c|c|c|c|c|c|c|c|c|}
\hline \multirow{2}{*}{ Species } & \multirow{2}{*}{$\begin{array}{l}\text { Total polyprenols } \\
\text { (\% of fresh weight) }\end{array}$} & \multicolumn{8}{|c|}{ Content of components (\%) } \\
\hline & & 14 & 15 & 16 & 17 & 18 & 19 & 20 & 21 \\
\hline Armillaria mellea & 0.01 & & & & & & & & \\
\hline Free & 0.003 & 5.2 & 10.5 & 17.5 & 32.5 & 32.6 & 8.4 & & \\
\hline Acetylated & 0.007 & 6.3 & 17.0 & 35.7 & 27.4 & 9.7 & 3.8 & & \\
\hline Fomes fomentarius & 0.0005 & & + & + & + & + & & & \\
\hline Tricholoma populinum & 0.007 & & & & & & & & \\
\hline Free & 0.0024 & 9.3 & 15.6 & 26.7 & 26.0 & 22.2 & Tr. & & \\
\hline Acetylated & 0.0056 & 13.5 & 21.7 & 32.7 & 28.5 & 3.6 & & & \\
\hline Lycoperdon perlatum & 0.007 & & & & & & & & \\
\hline Acetylated & 0.007 & & & & & 11.8 & 52.9 & 23.5 & 11.8 \\
\hline Suillus luteus & 0.00007 & & & + & + & + & + & & \\
\hline
\end{tabular}

\section{REFERENCES}

Chojnacki T. and Vogtman T. 1984. Occurence and seasonal distribution of $\mathrm{C}_{50}-\mathrm{C}_{60}$-polyprenols and $\mathrm{C}_{100^{-}}$and similar long-chain polyprenols in leaves of plants. Acta Biochim Polon, 31, 115-126.

Grigor'eva N. Y. and Moiseenkov A. M. 1989. Physiological activity of polyprenoids. Khim-Pharm Zh, 2, 145-155.

Kukina T. P., Demenkova L. I., Raldugin V. A., et al.
1991. Polyprenols and dolichols of sea buckthorn leaves. Sib Khim Zh, 6, 89-93.

Mankowski T.,Jankowski W., Chojnacki T., and Franke P. 1976. $\mathrm{C}_{55}$-dolichol occurence in pig liver and preparation by hydroge-nation of plant undecaphenol. Biochemistry, 15(10), 2125-2130.

Swiežewska E., Sasak W., Mankowski T., Jankowski W., Vogtman T., Krajewska I., Hertel J., Skoczylas E., and Chojnacki T. 1994. The search for plant polyprenols. Acta Biochim Polon, 41, 221-260. 